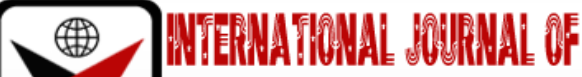

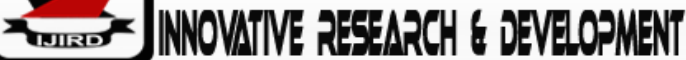

ISSN 2278-0211 (Online)

\section{The Precarious Position of Developing Countries in the Application of Customary International Law to Expropriation of Foreign Properties}

\author{
Dr. Adebisi L. Raimi \\ Senior Lecturer, Department of Law, Obafemi Awolowo University, Ile-Ife, Nigeria
}

\begin{abstract}
:
This article examines the precarious position of the developing nations of the world in the application of customary international law to expropriation of foreign properties. International custom as a source of International Law as well as the concept of expropriation, its variants and the requirements for a lawful expropriation are discussed in the article. The article further attempts to discuss critically the effect of the international custom on expropriation on the developing economies. The article is concluded by maintaining that customary rules relating to expropriation of properties by the developing countries should be substituted with more liberal rules of International Investment Agreements that take care of the economic development needs of the developing countries rather than a strict application of international customs that the parties have not consented to.
\end{abstract}

Keywords: International custom, expropriation and developing economies

\section{Introduction}

The sources of international law are contained in Article 38 of the Statute of the International Court of Justice. This article provides as follows: shall apply:

The Court, whose function is to decide in accordance with international law such disputes as are submitted to it,

- International conventions, whether general or particular, establishing rules expressly recognized by the contesting states;

- International custom, as evidence of a general practice accepted as law;

- The general principles of law recognized by civilized nations;

- Subject to the provisions of Article 59, judicial decisions and the teachings of the most highly qualified publicists of the various nations as subsidiary means for the determination of rules of law. ${ }^{1}$

This provision shall not prejudice the power of the Court to decide a case ex aequoet bono if the parties agree thereto.

Paragraph 2 of Article 38 provides for the settlement of international disputes in keeping with equity and good conscience as a subsidiary source of international law. ${ }^{2}$

In terms of its actual use, the Article has been a ready guide for practitioners in the determination of sources of international law, to gauge the pulse of the law. ${ }^{3}$ Apart from international custom, it has been stated that peremptory norms of international law are accepted and recognized by the international community as a whole and there can be no derogation whatsoever from them. ${ }^{4}$ The fact that peremptory norms are prevalent in customary rules means that developing countries are also expected to be bound by them even when they have not consented to those norms. However, the foundation stone of international law is the protection of sovereignty and the equality of states. Hence, it has been postulated that economic sovereignty is tied to economic emancipation. ${ }^{5}$

The present Statute of the International Court of Justice which has made international customary law a source of international law represented a written opinion of the World order at the end of the Second World War when a number of the present developing countries were still under colonial rule. Article 36 of the Statute of the International Court of Justice

${ }^{1}$ Summary of Customary International Law and Jus Cogens as Pertains to Juvenile Offenders; (2003/2004) $<$ htttx//www.intemationaliusticeproiect.org/juvJusCogens.cfin>, accessed on 10 thJune, 2019.

${ }^{2}$ See Article 38 of the 1946 Statute of the International Court of Justice (ICJ). See also Article 50 of the Vienna Convention on the Law of Treaties 1969. 3Jayakumar, K., 'Where Does Article 38 Stand Today?' <http://www.e-ir.info/2011/10/12/where-does-article-38-stand-todayd/>, accessed on 10thJune, 2018. See generally Nnabue, U.S.F. and Onyema Otitodiri (2015), Enforcement of International Custom on Expropriation of Foreign Properties and the Plight of Developing Countries, the Gravitas Review of Business and Property Law, Vol. 6, No. 1, p.75.

4 ibid

${ }^{5}$ Nnabue. U. S. F. (2012), The Dialectics of International Development Law and the Dilemma of Underdevelopment in the Developing Countries, Inaugural Lecture, Serial No. 8, Imo State University Press, Owerri, 34. 
emphasizes a consent-based legal system that hinges upon voluntary action. In reality, states are often bound by norms that they have not explicitly consented to, particularly, the jus cogens. In theory, states are bound to follow only those norms that they consented to, whether by signing a treaty or by believing that a custom binds them. ${ }^{6}$ This emphasizes the importance that when the developing countries consent to the existing international custom or when a particular international custom emanates from established practice to which they are parties, there will not be any controversy regarding such international custom as a peremptory norm of international law which the developing countries will willingly accept. Indeed, some of the international customs have colonial exploitative or neo-colonialism tendencies such as payment of compensation in cases of expropriation of foreign properties. The developing countries were invariably burdened with debts, concessions, servitudes or commercial arrangements from colonial periods. ${ }^{7}$ To take one example, if foreign-owned private properties could not be taken over in the public interest without the payment of prompt, full or adequate, and effective compensation, the developing countries might never be able to expropriate them and that would result to economic problems. Therefore, developing countries should not be bound by international custom merely because the developed countries supported them.

\section{International Custom}

International custom is the second source of international law listed in the Statute of the International Court of Justice. ${ }^{8}$ Thus, customary international laws are those aspects of international law that are derived from customs. Along with general principles of law and treaties, custom is considered by the International Court of Justice, jurists, the United Nations, and its member states to be among the primary sources of International law. 'It is constituted by two elements, the objective one which is the general practice and the substantive one which is the one accepted by law (opiniojuris).

In International Law, customary law refers to the Law of Nations or the legal norms that have been developed through the customary exchanges between states over time, whether based on diplomacy or aggression. Essentially, legal obligations are believed to arise between states to carry out their affairs consistently with past accepted conduct. These customs can also change based on the acceptance or rejection by states of particular acts. Some principles of customary law have achieved the force of peremptory norms, which cannot be violated or altered except by a norm of comparable strength. These are said to gain their strength from universal acceptance, such as the prohibitions against genocide and slavery.

International custom can be distinguished from treaty law, which consists of explicit agreements between nations to assume obligations. However, many treaties are attempts to codify pre-existing customary law. For rules to become international customs there must be, in the words of International Court of Justice (ICJ), 'a constant and uniform usage'10. In the Lotus case ${ }^{11}$, the Permanent Court of International Justice (PCIJ) found as follows:

That state laws are inconsistent, municipal decisions conflicted, text writers were divided; consequently, no uniform trend was discernible to support the existence of a custom giving a Flag State exclusive penal jurisdiction over ships in collisions at sea. ${ }^{12}$

However, in Panquete Habana ${ }^{13}$ the US Supreme Court was convinced that a custom has arisen exempting small fishing vessels from belligerent action in a blockade. The law is that the state must act under the impression that the action is obligatory in law. ${ }^{14}$ The ICJ stressed in the North Sea Continental Shelf Case ${ }^{15}$ that states must feel impelled by a legal obligation. Custom must be distinguished from mere usage. A rule of customary international law derives its force of law through the behaviour and practice of states and subjective conviction held by states that the behaviour in question is compulsory and not discretionary. ${ }^{16}$

The questions remain- what is the effect of international custom that a state did not consent to? What is the effect of international custom that a state feels it has no obligation to accept? Is there justice in compelling a state party to be bound by international custom that will impede its economic development policies? Thus, the position of the law as contained in Article 38 (c) of the Statute of the ICJ deserves further attention. The attention is that it invariably weakens developing countries' economic sovereignty and the right to economic self-determination. This, by implication, will hinder lawful expropriation of properties and consequently make the concept of expropriation a mirage. It can also manifest in the erosion of permanent sovereignty and exclusive privileges over the economic activities, wealth and natural resources of the developing countries. It is based on the above, that Akpotaire posited that the new economic world order of free trade and the manipulations by the international financial institutions in ensuring that Foreign Direct Investmen (FDI) status-quo is not changed in favour of Nigeria and other developing countries, has given rise to various critical questions. ${ }^{17}$ According to him, the World Trade Organization (WTO), the World Bank and the International Finance Corporation, the

6Jayakumar K., Op. Cit.

7 See Anand R P, 'Role of the 'New' Asian Countries in the Present International Order (1962)56 AJIL 384-5 cited in Umozurike, U. 0, (1999), Introduction

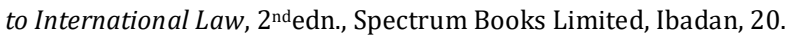

${ }^{8}$ See Nicaragua v. USA [1986] ICJ Rep, 14, 97.

${ }^{9}$ ‘Customary International Law 'http, Accessed 10 January, 2020.

${ }^{10}$ The Asylum Case, (1950), ICJ Rep. 266,276-7.

11(1927), PCIJ, Series A, No. 10.

12Ibid, Pp. 22-3.

13 (1900)175 US 677

14 This is often expressed as opinion jurissive necessitates or simply opinion juris.

${ }^{15}$ (1969) ICJ Rep. 116.

${ }^{16}$ Aydogan, R.C., 'State measures affecting the property of foreign investors: expropriation or regulation? http://www.ankarabarosu.org.tr/siteler/ankarabarreview/tekmakale/2011-2/4.pdf, Accessed 10 January, 2020.

${ }^{17}$ Akpotaire, V. 0. (2012), 'International Investment and Globalization of World Trade: an African Legal Perspective,'11, JICL 1. See also Nnabue, U.S.F. and OnyemaOtitodiri (2015), Enforcement of International Custom on Expropriation of Foreign Properties and the Plight of Developing Countries, the Gravitas Review of Business and Property Law, Vol. 6, No. 1, p.77. 
International Monetary Fund (IMF), and the Group of Eight Industrialized Countries (G8) have variously played dominant roles in determining, at any given time, the flow of international capital to the critical regions of the world. These have been achieved predominantly through the various strategic activities of multinational and trans-national corporations; tying development aids to structural adjustments and paradigm shift in development policies, and the new policy of globalization of world trade and investment which is critically conditioned upon open market economies that often shrinks the sovereignty of developing countries. ${ }^{18}$ The author argued that this development often limits the capacity of developing countries to formulate domestic policies capable of impacting on the movement of private foreign capitals into their respective economies. In the same way, as Akpotaire has posited, it is submitted that this position is applicable where states are meant to observe international customs that they do not consent to.

\section{Expropriation}

In assessing the state of international law with regard to the expropriation of the property of aliens, one is immediately confronted with two opposing objectives, although they need not be irreconcilable in all cases. On the one hand, the capital-exporting countries require some measure of protection and security before they will invest abroad and, on the other hand, the capital-importing countries are wary of the power of foreign investments and the drain of currency that occurs, and are often stimulated to take over such enterprises ${ }^{19}$. Nationalisation for one reason or another is now a common feature not only in Communist and Afro-Asian states, but also in Western Europe. The need to acquire control of some key privately owned property is felt by many states to be an essential requirement in the interests of economic and social reform. ${ }^{20}$

Customary international law gives to States the power and right to expropriate the properties of foreign investors as long as it is on the ground of public purpose; it is not as a result of discrimination; it follows the due process of law; and also provides prompt, adequate and effective compensation to the affected party. ${ }^{21}$ Expropriation can simply be referred to as the taking of property by the State or the transfer of a person's property by the State to other economic operators. ${ }^{22}$ Kapoor had maintained that despite the fact that there used to be a great controversy as regards the expropriation of foreign property situated in a State, in the modern period, significant changes have taken place in this connection ${ }^{23}$. Till the 19th century, if any State expropriated the foreign property it was considered to be the violation of international law making the said State liable for the same. However, in the modern period, in view of the complete control of States over their economic system and in consequence of the nationalisation of different industries, it has become difficult to recognize such expropriation as the violation of international law. ${ }^{24}$

$\mathrm{O}^{\prime}$ Brien is of the opinion that the taking of the property of foreign investors is one of the commonest problems in the law of state responsibility25. It is normally; a matter for each state to decide whether to accept foreign investment or not, but if it decides to do so then public international law sets out a number of rules as to how it treats the foreign investors. In general terms, the foreign investors are expected to abide by the laws of the host state; however, problems may arise as to the conduct of such foreign investors. Sometimes, such difficulties can be avoided by setting out minimum standards in a bilateral investment agreement. In this area of international law, there has traditionally been a problem of differences of opinion between capital exporting countries and capital importing countries. The law of state responsibility often becomes relevant when a host state decides to expropriate the assets of a foreign investor ${ }^{26}$

In accord with other scholars, Starke had also asserted that in the nineteenth century, any expropriation of the property of a foreign citizen would have been regarded as a clear basis for an international claim. He reiterated further that at the present time, however, the widening control by states over the national economy and over almost every aspect of private enterprise, and the measures of nationalisation of different industries adopted by so many states, make it difficult to treat, as contrary to international law, an expropriation of foreign property for a public purpose in accordance with a declared domestic policy, applied without discrimination to the citizens of the expropriating state and to aliens alike. ${ }^{27}$

${ }^{18}$ Akpotaire, V. O., Opp. Cit. at p.1

${ }^{19}$ Malcolm N. Shaw (2008), International Law, 6th ed., Cambridge, Cambridge University Press, P. 828

20Ibid.

${ }^{21}$ Peter D. Isakoff (2013), 'Defining the Scope of Indirect Expropriation for International Investments', 3, the Global Business Law Review, 189. See also Lolade Odemuyiwa (2014), Indirect Expropriation and the Regulatory Powers of the State, Ife Journal of International and Comparative Law, Vol. 1, No. 2, 260 .

22United Nations Conference on Trade and Development, Expropriation: UNCTAD Series on International Investment Agreements (Pink Series, Cm II, 2012), 5-6.

${ }^{23}$ See Kapoor, S.K. (2011), International Law and Human Rights, 18 th Edition, Central Law Agency, Allahabad, p.145.

${ }^{24}$ Ibid.

25 See John 0.' Brien (2001), International Law, Cavendish Publishing Limited, Great Britain, 382 . O.' Brien was actually corroborating Professor Schachter who had observed earlier that: 'Apart from the use of force, no subject of international law seems to have aroused as much debate - and often strong feelings - as the question of the standard for payment of compensation when foreign property is appropriated' (1984)78 AJIL 121.

${ }^{26}$ John O' Brien, Opp. Cit., 383.

27 See J. G. Starke (1994), Introduction to International Law, 11th edition, London, Butterworth \&Co. (Publishers) Ltd.p.498. Note also the provision in Art. 2 Para. 3 of the Covenant on Economic, Social and Cultural Rights of 16 December 1966, that developing countries, 'with due regard to human rights and their national economy', may determine to what extent they will guarantee to non-nationals the economic rights recognised in the Covenant. In its Resolution on permanent sovereignty over natural resources, adopted on 17 December 1973, the United Nations General Assembly affirmed that each nationalising state, by virtue of its sovereignty to safeguard over natural resources, it entitled to determine the amount of possible compensation and the mode of payment, and that any disputes should be settled in accordance with the domestic legislation of that nationalising state. An affirmation in somewhat similar terms appears in sub-para (c) of para 2 of art 2 of the Charter of Economic Rights and Duties of States adopted by the General Assembly in 1974; this contains a reference to the payment of 'appropriate compensation', and provides for the settlement of any controversy by the domestic tribunals of the nationalising state, 'unless it is freely and mutually agreed by all States concerned that other peaceful means be sought on the basis of the sovereign equality of States and in accordance with the principle of free choice of means'. 
In his own case, Agarwal had stated that that the private property of the aliens should be respected is a recognized principle of International Law. If a State fails to protect it, it becomes responsible under International Law ${ }^{28}$. However, the expropriation of alien property for public purposes has not been considered to be contrary to International Law. It is generally agreed that this right is implied in the sovereignty of the State. However, the right is permissible solely for public purposes. It must not be arbitrary and must not be based on the application of duly adopted laws. The acts of a government in depriving an alien of his property must be followed by grant of prompt, effective and adequate compensation..$^{29}$

The rationale for expropriation is based on the doctrine of economic sovereignty which in turn is derivable from the principle of economic self-determination. This is to say that states have the inalienable right to determine both their economic system and future without interference by or reference to another state or group of states. Many scholars and jurists have different opinions on the right of states to expropriate foreign properties within their national boundaries. It is important first to consider proposition advanced by the 'acquired or vested' rights theorists who proposed that when a certain status or legal right has been acquired under municipal law of a state, such status or right must be respected as a matter of international obligation. ${ }^{30}$ That is to say that once a municipal law confers a right to own property on an alien, that same jurisdiction should not take away such property by way of expropriation. According to these theorists, it is an obligation in international law that the alien be allowed to continue to enjoy the right.

The assertion that an alien be allowed to continue to enjoy the right to own property conferred on him by the municipal law of a State has been anchored more on the American case of U.S. A.V. Perchman, ${ }^{31}$ where Marshall C.J. said:

.... that sense of justice and of right which is acknowledged and felt by the whole civilized world would be outraged, if private property should be generally confiscated and private rights annulled. The people changed their allegiance, their relation to each other and their rights of property remained undisturbed. ${ }^{32}$

This view therefore sees expropriation as simply illegal, being a violation of the so-called vested right. ${ }^{33}$ However, this argument cannot be pushed too far. It fails to conform with the concept of sovereignty upon which the operation of international law is based. A state has exclusive right and competence to determine the character of its own institutions to ensure and provide for their operation and to enact its own laws and ensure their execution. ${ }^{34}$

As a result of numerous criticisms levelled against the 'vested rights' theory, especially by the developing countries, its proponents shifted position. They contended that the principle of 'acquired right' does not mean that these rights may not be interfered with at all, but that the title holders must be indemnified from complete and arbitrary destruction of their interest. ${ }^{35}$ In this regard, the proponents of this view insist that expropriating states should apply the minimum standard of treatment to aliens when nationalization occurs. By this, it is meant that the nationalizing state should add rather than subtract from the international protection which nationals would enjoy in any case. It is argued that the minimum standard has grown to a rule of customary international law taking precedence over the standard of 'national treatment' which ensures the enforcement of personal and property rights of citizens alike. These being the case, nationalizing states are expected to pay full compensation. ${ }^{36}$

However, the developing countries prefer the national treatment. That is, giving foreigners the same type of punishment as nationals with regard to type of compensation. Hence, national constitutions of the developing nations make provision for property protection. For example, the Constitution of Nigeria ${ }^{37}$ in Section 44 provides as follows:

- No moveable property or any interest in an immovable property shall be taken possession of compulsorily and no right over or interest in any such property shall be acquired compulsorily in any part of Nigeria except in the manner and for the purposes prescribed by a law that, among other things-

- requires the prompt payment of compensation thereof; and

- gives to any person claiming such compensation a right of access for the determination of his interest in the property and the amount of compensation to a court of law or tribunal or body having jurisdiction in that part of Nigeria...

- The above provision is in recognition of the right of expropriation and compensation. The right to resort to the law courts is conferred on all and sundry under the Nigerian constitution.

\section{Indirect Expropriation}

A State may, in pursuance of its economic programmes, nationalize foreign-owned property by legislation. When this happens, it results in an immediate and outright vesting of the property in the hands of the State or a State entity created for this purpose. There is no particular legal problem in identifying such measures. Little wonder why attempts have always been made to narrow the definition of expropriation to outright expropriations accomplished by legislation ${ }^{38}$.

${ }^{28}$ H.O. Agarwal (2013), International Law and Human Rights, 19th ed., Allahabad, Central Law Publications, P. 267

29Ibid.

${ }^{30}$ Francioin, F, 1975, 'Compensation for Nationalization of Foreign Property: The Border Land between Law and Equity', 24 ICLQ 259.

317 peters US Supreme Court Reports 86

32Ibid, Pp. 97-9

33Francioni, F. Opp. Cit., 259

${ }^{34}$ Mugerwa, PJK, 1978, Subjects of International Law (Manual of Public International Law), macmillan, 253

35Francioni, F. Opp. Cit., 259

36Umozurike, Opp. Cit., 20.

37 Constitution of the Federal Republic of Nigeria, Cap C23, LFN, 2004

38 M. Sornarajah (2010), The International Law on Foreign Investment, 3 $3^{\text {rd }}$ edn., Cambridge University Press, 367-69. See also Ali Ghassemi 1999,

Expropriation of Foreign Property in International Law, Unpublished Ph. D. Thesis Submitted for the Degree of Doctor of Philosophy in International Law in the University of Hall, p.192. 
However, in the Biloune case, the tribunal held that no distinction should be made between direct and creeping expropriations ${ }^{39}$.In addition to direct expropriation, therefore, it is evident that there could be other instances of interferences with property rights which could amount to expropriation of foreign property for which the State may be responsible. ${ }^{40}$ Dolzer had maintained that historically, State measures affecting property rights in an indirect manner have not been as prominent in State practice as they are now in the modem interventionist type of State. ${ }^{41}$

Though the concept of 'indirect expropriation' is not a new phenomenon, ${ }^{42}$ its definition is by no means settled. There is no general rule or definition that describes the concept of indirect expropriation. What constitutes indirect expropriation differs and is blurred by different definitions proffered by tribunals, judges, international investment instruments, and the opinions of writers. ${ }^{43}$ This, as a result, poses a serious difficulty to the idea of reaching a unanimous definition of the concept based on the fact that everyone tends to view the elephant from different angles. Another reason why this concept cannot be assessed through a single principle is that it takes place within a wide variety of circumstances and it is assessed according to the peculiarity of each case. ${ }^{44}$. It could, therefore, be argued that any type of governmental interferences with deprivation of alien property which has not taken place as a result of direct legislation or executive action amounts to an indirect expropriation. Conversely, it could also be contended that not all governmental interferences with the peaceful rights of use, enjoyment and control of property by aliens do constitute expropriation incurring the responsibility of the host State, and hence attract the concern of international law. Thus, there are some problems in offering a precise definition which clearly identifies all governmental interferences.

One scholar recognized the difficulty of delimiting the subject and observed that it is nearly impossible to define with precision the meaning of indirect expropriation ${ }^{45}$. It has been suggested that 'the complexity of the situations and endless possibilities of State intervention in the property rights of private persons make it impossible to give a straightforward definition of the subject.46 To avoid the problem, Sornarajah ${ }^{47}$ had observed that in a sense, expropriations may be divided into two categories, namely 'compensable expropriations' and 'regulatory expropriations'. It is more appropriate to identify the types of expropriations that are considered as 'compensable expropriations' than to devise a criterion for the category of interferences which do not amount to expropriation, and hence engage the responsibility of the State, referred to as 'regulatory expropriations'.

Nevertheless, some attempts have been made to define the concept of indirect expropriation. For example, in some efforts at codification of international law relating to expropriation of alien property, attention has been paid to the issue of indirect deprivation or expropriation. In this regard, Article 10(3) (a) of the 1961 Harvard Draft Convention on International Responsibility for Injuries to Aliens (sometimes referred to as the Sohn-Baxter Draft Convention) defines a taking of property as including:

not only an outright taking of property, but also any such unreasonable interference with the use, enjoy mentor disposal of property as to justify an interference that the owner will not be able to use, enjoy or dispose of the property within a reasonable period of time after the inception of such interference ${ }^{48}$.

In their explanatory note to this article, Sohn and Baxter stressed that the duration of an interference with the use, enjoyment and disposal is the main factor in determining whether an expropriation has taken place or not, and the adjudicator of the claim possesses a considerable power in this respect. 49

Different authors often refer to indirect expropriation by different words or terminologies such as creeping expropriation $^{50}$, disguised expropriation ${ }^{51}$, constructive taking 52 , de facto expropriation ${ }^{53}$, etc. The same words have been

${ }^{39}$ Biloune v. Ghana Investment Centre, 95 ILR, pp.183 at 207-10.

40 Ali Ghassemi, Opp. Cit.

${ }^{41}$ R. Dolzer (1986), 'Indirect Expropriation of Alien Property', 1 I.C.S.I.D. Rev-F.I.L.141 at

142.

42 During the 1917 Mexican Agrarian Reforms, a United States' Note to Mexico stated that the

US Government could not acquiesce in any direct and indirect confiscation of foreign-owned

properties in Mexico. See further, Jain, op. cit., at 34.

${ }^{43}$ M. Sornarajah, Opp. Cit. See also Lolade Odemuyiwa (2014), Indirect Expropriation and the Regulatory Powers of the State, Ife Journal of International and Comparative Law, Vol. 1, No. 2, 260

44 Ibid

45 S. D. Metzger, 'Multinational Conventions for the Protection of Private Foreign

Investment', 9 J.P.L. (1960) 157.

46Piran, op. cit., at 143.

${ }^{47}$ Somarajah, op. cit., at 283.

${ }^{48}$ Reprinted in 55 A.1.I.L. (1961) 545 at 553.

49 Ibid., at 559.

${ }^{50}$ See, inter alia, B. H. Weston (1975-76), 'Constructive Takings under International Law: A Modest

Foray into the Problem of Creeping Expropriation', 16 Virgo ll.L., 103 and The ALI

Third Restatement US Foreign Relations Law (1987), Vol. 2, Section 712, 196 at 200. See further K. C. Kotecha, 'Comparative Analysis of Nationalization Laws: Objectives and

Techniques', 8 CLL.J.S.A. (1975) 87 at 92. Note that the author used the term 'indirect seizure';

Higgins, op. cit., at 322; S. C Jain, Nationalization of Foreign Property - A Study in North-South

Dialogue, Deep \& Deep Publications, New Delhi (1983) at 34; Dolzer, op. cit., at 44; Sornarajah,

op. cit., at 282, and Piran, op. cit., at 140 .

${ }^{51}$ The Separate Opinion of Judge Sir G. Fitzmaurice in the Barcelona Traction Light and

Power Company, Ltd., case, (Belgium v. Spain), I.C. J. Rep. (1970) 65 at 106; the case of

ElettronicaSigula S.P.A. (ELSJ), (United States of America v. Italy), Award of 20 July 1989,

I.C.J. Rep. (1989) 14 at 69, (para. 116), 70 (para. 118) and 71 (para. 119), and M. Akehurst, $A$

Modern Introduction to International Law (6th ed.), Routledge, London (1987) at 95.

52Weston, op. cit., at 103; I. Seidl-Hohenveldern, International Economic Law, Martinus

Nijhoff, Dordrecht (1992) at 155, and the latter writer's other literature, 'Aliens, Property', Vol. 
employed in arbitral decisions. Terms such as 'creeping', 'disguised' or 'constructive' expropriation, while providing a label for expropriations outside the obvious situation of formal expropriations of physical property, do little to help in the identification of indirect expropriations which will attract the application of international law on expropriation ${ }^{54}$. Likewise, these terms suggest a deliberate strategy on the part of the host State to deprive the alien, which could happen in some circumstances, but is not the case in all instances ${ }^{55}$. Thus, the term 'indirect expropriation' is preferred here. Although we must bear in mind the above-mentioned defects, it is important to consider the neutrality of the term, which is helpful in any analysis.

It has to be stated that in modem literature and arbitral awards, indirect expropriation has received special attention. Several facts contributed to this. First, in contrast to a laissez faire State, the imperatives of welfare States have led them to interfere frequently with the property rights of private persons, including aliens. But often such interference or action falls short of direct expropriation ${ }^{56}$. Secondly, under certain circumstances, States can diminish property rights without affecting direct ownership of the investment. For instance, when the management of a company is taken over, the company, its assets and shares are not affected but the foreign investors' interests are decreased ${ }^{57}$.

Again, it must be noted that there are certain factors that constitute or determine indirect expropriation. Going by the provision of annex 13 of China-New Zealand FTA, the elements that characterize the concept of indirect expropriation can be said to include: a substantial, severe or permanent deprivation; disproportionality; discrimination; and a breach of legitimate expectations. ${ }^{58}$ However, for a much clearer understanding and analysis, these elements or factors can be divided into three major groups, namely, deprivation of the economic value of the investment; interference with the legitimate expectations of the investor and the nature, purpose and character of the measure. ${ }^{59}$

\section{Requirements of a Lawful Expropriation}

States have a sovereign right under international law to take properties held by nationals or aliens through nationalization or expropriation for economic, political, social or other reasons. ${ }^{60}$ In order to be lawful, the exercise of this sovereign right requires that the following conditions be met:

- Property has to be taken for a public purpose;

- On a non-discriminatory basis;

- In accordance with due process of law;

- Accompanied by compensation. ${ }^{61}$

In this regard, expropriations of properties do not trigger the international responsibility of expropriating state as long as these requirements are met. While the right of states to expropriate is recognized as a fundamental one, the exercise by states of this right has triggered conflicts, debates and disagreements that are far from over, although the tone and content, coupled with the procedural means to settle disputes, have varied significantly over time. ${ }^{62}$ Through International Investment Agreements (IIAs), states have established a guarantee for foreign investors against the expropriation of their investments, without compensation. At present, virtually all Bilateral Investment Treaties (BITs) contain expropriation provision. Customary international law also contains rules on the expropriation of foreign owned property and continues to supplement International Investment Agreements (IIAs) on the issues where the latter leave gaps or require interpretation. ${ }^{63}$

For instance, from 1960, when Nigeria attained her independence, the issue of compensation became constitutional matter. ${ }^{64}$ This was in addition to a majority of other laws regulating issues of compensation. ${ }^{65}$ Most of these laws equally provide for the payment of compensation to holders whose rights of occupancy were compulsorily acquired by government for overriding public interest ${ }^{66}$. Accordingly, compensation is a concept which many Nigerians are familiar with within terms of statutory and constitutional provisions but dissatisfied and left in doubt with regard to the manner and ways by which it is assessed or computed. ${ }^{67}$ The situation is particularly worrisome considering the divergent views expressed by both developed and developing countries on the applicable international custom.

Today at the international level, the disputes before the courts and the discussions in academic literature focused mainly on the standard of compensation and measuring of expropriated value. The divergent views of the developed and

8, Encycl. P.I.L., 20 at 21.

${ }^{53}$ See e.g., N. R. Doman, 'Post War Nationalization of Foreign Property in Europe'. 48

Col.L.R. (1948) 1125 at 1129, and Vernie R. Pointon et al. v. The Islamic Republic of Iran,

Award No. 516-322-1 (23 July 1991), reprinted in 27 Iran-U.S. CT.R. 49 at 59, para. 32, and at

61, para. 36.

${ }^{54}$ Sornarajah, op. cit., at 282

55Piran, op. cit., at 140.

56 See Ali Ghassemiop. cit., at 193.

57Ibid.

${ }^{58}$ China-New Zealand FTA, 2008, annex 13

59UNCTAD, (n 3) 62-3

${ }^{60}$ United Nations Conference on Trade and Development, 'Expropriation', UNCTAD Series on Issues in International Investment Agreement,11,2012http://unctad.org/en/Docs/uuctaddiaeia20l1d7 en.pdf, accessed on 10 thJune, 2018.

61Ibid.

62 Ibid 1

${ }^{63}$ Ibid 5

${ }^{64}$ See Section 44 of the 1999 Constitution of The Federal Republic of Nigeria, as amended.

${ }^{65}$ See Section 62, Mineral and Mining Act, Cap.M12, LFN, 2004; Section 29, Land Use Act, Cap., L5, LFN, 2004.

${ }^{66}$ Atedze, W. A, 'Compulsory Acquisition and Compensation: Position of the Courts and the Land Use Act in Nigeria', op.cit

67Ibid. 
developing countries raised issues regarding the formation and evolution of customary law. ${ }^{68}$ A number of developed countries endorsed the 'Hull formula'. Hull claimed that international law requires 'prompt, adequate and effective' compensation for the expropriation of foreign investments. Developing countries supported the Calvo doctrine during the I960s and 1970s as reflected in major United Nations General Assembly resolutions. In 1962, the General Assembly adopted its Resolution on Permanent Sovereignty over Natural resources which affirmed the right to nationalize foreign owned property and required only 'appropriate compensation'. This compensation standard was considered an attempt to bridge differences between developed and developing states. In 1974, the United Nations General Assembly decisively rejected the Hull formula in favour of the Calvo doctrine in adopting the Charter of Economic Rights and Duties of States. While Article 2(c) of the Charter repeats the 'appropriate compensation' standard, it goes on to provide that:

...in any case where the question of compensation gives rise to a controversy, it shall be settled under the domestic law of the nationalizing State and by its tribunals...

In the present times, the Hull formula and its variations are often used, accepted and considered as part of customary international law as argued by the developed countries. However, this has not been accepted by the developing countries. It is obvious that the developed countries did not consult the developing countries before such rule was adopted as an international customary law. It is also true that the developing countries did not consent to such customary rule. Why then should this so-called customary rule be binding on the developing countries? It is objectively reasoned here that the best practice would be to allow the developing countries to enter into and adopt treaty obligations that will reflect their economic development policies and allow these obligations over time to metamorphose into international customary law. The idea of imposition of international custom as a source of international law from the above is certainly an erosion of the concept of sovereignty and the right of host state to expropriate foreign properties for public purposes.

\section{Effect of the International Custom on Expropriation on Developing Economies}

Having discussed the argument for and against the vested rights theory, it appears important to examine the rationale for expropriation further; particularly as regards the effect on developing countries as a result of insistence on international customs. In any case, the 'vested rights' theorists have agreed that states can expropriate but that there should be compensation hinged on the minimum standard of treatment and that this has crystallized into international customary rule.

The doctrine of economic sovereignty from which the rationale for expropriation is drawn cannot be successfully presented without recourse to the attitude of South American States. The South American States were the first to practice the rights of states to determining the economic relations with foreign investors. This therefore, makes relevant the Calvo Clause, which also presents an argument of international customary rule. In a bid to stop the unnecessary interference in the affairs of his state by powerful nations, a South American diplomat (Argentine), Carlo Calvo propounded the 'Calvo Clause.' Simply put, the Calvo Clause is a term in a contract between an alien and a government whereby the alien agrees not to call upon his state of nationality for protection on any issue arising out of the contract. It was directed against the European states that constantly intervened diplomatically when there was minor disagreement between their nationals and the governments of South American nations arising from business relations. In its operative form, the Calvo clause contains stipulation that in the event of any dispute arising out of contract, the alien contractor shall be subject to the jurisdiction of the courts of the contracting states. Additionally, that the applicable law shall be the law governing such contracts in the host state or any such law as agreed between the parties in the contract. The most important stipulation of a Calvo clause is that which requires the alien to waive the protection of his home. ${ }^{69}$ As expected, jurists from the industrialized west found the idea objectionable. They contended that individual is incapable of renouncing rights which are inherent in his nation state, that the state is not bound by the individual's renunciation of rights which belong to his state. The alien however, has freedom of contract in any manner he chooses. What the alien is waiving is not the right of diplomatic protection possessed by the state of his nationality but his power to request the exercise of that right in his favour. It is difficult to admit that such protection will or may be exercised in the face of a concluded agreement that no such request will be made to the state of nationality.

It could be seen that the sole aim of the Calvo clause which was proposed first in 1886, is to ensure national sovereignty and not necessarily depriving other states the right to protect their citizens diplomatically. It ensures not only state sovereignty over all subjects but also equal treatment of aliens and nationals alike. Drawing from the above view introduced by the calvo doctrine, and the insistence by the developing nations that they have the right to determine what happens within their territories, there is the agreement that states can now expropriate. However, the idea of payment of compensation after such expropriation is still an issue in international law.

In a reply to the U.S. demand for the payment of prompt, adequate and effective compensation subsequent to the Mexican nationalization laws of the 1930s, the Mexican government stated that:

the jurisdiction of the states within the limit of national territory is applicable to all inhabitants. Nations and foreigners cannot claim rights different from or more extensive than nationals (sic)... as your government is not unaware that our Government finds itself unable to pay the indemnity to all affected by the agrarian reform, by insisting on payment to American landholders it demands, in reality, a special privileged treatment which no one is receiving in Mexico. 70

${ }^{68}$ OECD at <http://www.oecd.org/investment/investmentpolicy/33776546.pdf>, op.cit.

${ }^{69}$ Lipstein k., 1945, 'The place of the Calvo clause in International Law', 22 BYIL. 130

${ }^{70}$ Department of State Press, Released $3^{\text {rd }}$ August, 1939; cited by Francioni, Opp. Cit., 269 
Countering this position, the U.S. which country invariably represents the interest of the industrialized world has argued through its secretary of state, Mr. Cordell Hull as follows:

Under every rule of law and equity, no government is entitled to expropriate private property, for whatever purpose, without provision for prompt, adequate and effective payment therefore. ${ }^{71}$

The issue of payment of prompt, adequate and effective compensation or non- payment of compensation, apart from right of expropriation became a vexed issue in International law. No wonder then that this was recognized in the popular case of Banco Nacional Da Cuba v. Sabatino ${ }^{72}$ thus:

There are few if any issue in International Law today on which opinion seems to be divided as the limitations on a state's power to expropriate the property of aliens. There is, of course, authority, in international judicial and arbitral decisions in the expressions of national governments and among commentators; for the view that a taking is improper under international law if it is not for a public purpose, is discriminatory, or is without provision for prompt, adequate and effective compensation. However, communist countries although have in fact provided a degree of compensations after diplomatic efforts, commonly recognize no obligation on the part of the taking country. Certain representatives of the newly independent and under developed countries have questioned whether rules of states responsibility toward aliens can bind nations that have not consented to them and it is argued that the traditionally articulated standards governing expropriation of property reflect imperialistic interest and are inappropriate to the circumstances of emergent state. ${ }^{73}$

This was the prevailing situation in International Law that prompted the United Nations to formalize its stand on the conflicting views. This came in the form of resolutions ${ }^{74}$ and they were made possible as a result of the pressure mounted by the newly independent nations of Africa, Asia and Latin America. However, the problem continues to persist at the international level as these resolutions are sometimes regarded as non-binding.

Until 1945, international law was dominated by European powers who were the main actors and laid down the rules. $^{75}$ The rules of International Law were invariably geared to the protection of the interests of its main actors and were indeed the instruments for the subjection and exploitation of the weaker states. ${ }^{76}$ The erstwhile subjugation of the colonial territories that won independence mostly since the end of the Second World War had been carried out under the prevailing International Law. Many aspects of the law, particularly on international custom on expropriation, were precisely against their interests. The new states invariably joined the Non-aligned group of countries and refused to be associated, as a matter of policy, with any side of the code war. It was also necessary for them to attract help from the developed countries in order to revive their exploited, yet undeveloped economies. They believed in a world ruled by law where the vagaries of economic, military or other power will not be index for the enjoyment of the legal rights within the community of states. The developing countries wanted the obnoxious rules to be replaced by progressive ones that would be mutually advantageous. ${ }^{77}$ They also wanted to retain what they have and make the best use of them, so they rejected the traditional rules for expropriation of foreign-owned private property.

The provision of Article 38(c) of the Statute of the International Court of Justice is not favourable to the economic development of the developing countries in the event of expropriation of foreign owned property for public purpose so long as it requires enforcement of international customs that the parties have not consented to. States are bound to follow only those norms that they have consented to, whether by signing a treaty thereof or by believing that the custom is binding on them. Additionally, several commonly followed practices are grouped under the heading of 'general principles of law'. In reality, states are actively bound by customary international norms that they have not quite consented to. For example, the Security Council in pursuing its mandate, ${ }^{78}$ passes resolutions with a fifteen-state body ${ }^{79}$ that bind other states even though they have not consented to the same. This trend is absolutely unfair in the modern world. Therefore, customary rules relating to expropriation of properties by the developing countries should be substituted with more liberal rules of International Investment Agreements that take care of the economic development needs of the developing countries rather than a strict application of international customs that the parties have not consented to. It will be a welcome development if such international customs are allowed to emerge from Investment Agreements and resolutions of international institutions to which the parties consented to rather than insistence on non-acceptable old international customs formulated by the developed countries alone. Such lopsided international customs will certainly perpetuate economic backwardness of the developing countries. It is posited here that repeated or frequent treaties and international institutions' resolutions mutually agreed upon between developing countries and the developed countries will increasingly become, not merely evidence, but in fact, the required acceptable international customs.

\section{Conclusion}

International law cannot afford to be watered down. Starting at the top, there are so many questions as to what the law itself is, and what the true source is all about. Even though International law is regarded as soft law by some jurists, one cannot turn a blind eye to the areas as above that require urgent consideration and improvement. The sources of the law are fraught with irregularities and questions still remain. Although Article 38 of the Statute of the International

\footnotetext{
${ }^{71}$ See A S K Asante, 1981, Transnational investment law and National development, university of lagos press, .

72(1964), 376 US 398.

73Ibid

${ }^{74}$ See Resolution 1803, XVII, Resolution 3201, Resolution 3202 and Resolution 3281.

75 U. O. Umozurike, 1999, Introduction to International law, $2^{\text {nd }}$ edn. , Spectrum Books Limited, Ibadan, 12.

76 Ibid

77 Ibid 14

${ }^{78}$ See Chapter VII of the United Nations (UN) Charter

79 This body includes five permanent members and ten non-permanent members.
} 
Court of Justice has helped to define international law as a discipline distinct from politics and international relations, it has fallen short of seeing the process through. As dynamic as society is, law needs to be one step ahead to ensure that there is a means to keep actions and omissions in check. ${ }^{80}$

It is noted that Article 38(c) is also silent on persistent objectors (states that object to a usage before it becomes a custom), subsequent objectors (states that object to a customary practice after the usage has evolved into a custom), and their role in the evolution of customary international law. The Article makes no mention of opiniojuris. ${ }^{81}$ It does not even speak of how many states must follow a practice in order for it to be considered a custom; nor does it say how one may determine the existence of a customary practice itself. The role of regional customary practice is also excluded. The consequent complications are plenty, since states bear the burden of proving that they are either bound or not bound by a specific custom or practice. Therefore, reviewing Article 38(c) of the Statute of the International Court of Justice will augur well for the evolution of acceptable and enforceable international customs.

\section{References}

i. A S K Asante, 1981, Transnational investment law and National development, university of lagos press.

ii. Akpotaire, V. O. (2012), 'International Investment and Globalization of World Trade: an African Legal Perspective,'11, JICL 1.

iii. Ali Ghassemi 1999, Expropriation of Foreign Property in International Law, Unpublished Ph.D.

iv. Anand R P, 'Role of the 'New' Asian Countries in the Present International Order (1962)56 AJIL 384-5

v. Atedze, W. A, 'Compulsory Acquisition and Compensation: Position of the Courts and the Land Use Act in Nigeria'

vi. Aydogan, R.C., "State measures affecting the property of foreign investors: expropriation or regulation? http://www.ankarabarosu.org.tr/siteler/ankarabarreview/tekmakale/2011-2/4.pdf, Accessed 10 January, 2020.

vii. B. H. Weston (1975-76); Constructive Takings under International Law: A Modest Foray into the Problem of Creeping Expropriation; 16 Virgo ll. L., 103.

viii. Francioin, F, 1975, 'Compensation for Nationalization of Foreign Property: the Border Land between Law and Equity', 24 ICLQ 259.

ix. H.O. Agarwal (2013), International Law and Human Rights, 19th ed., Allahabad, Central Law Publications, P. 267 Investment; 9 J.P.L. (1960) 157.

x. J. G. Starke (1994), Introduction to International Law, 11th edition, London, Butterworth \&amp; Co.(Publishers) Ltd.p.498.

xi. Jayakumar, K., 'Where Does Article 38 Stand Today?' \&lt;http://www.e-ir.info/2011/10/l2/where-does-article38-stand-todayd/\&gt; accessed on 10 th June, 2018.

xii. John O.' Brien (2001), International Law, Cavendish Publishing Limited, Great Britain, 382.

xiii. K. C. Kotecha; Comparative Analysis of Nationalization Laws: Objectives and Techniques; 8 CLL.J.S.A. (1975) 87 at 92.

xiv. Kapoor, S.K. (2011), International Law and Human Rights, 18th Edition, Central Law Agency, Allahabad, p.145.27

xv. Lipstein k., 1945, 'The place of the Calvo clause in International Law', 22 BYIL. 130

xvi. Lolade Odemuyiwa (2014), Indirect Expropriation and the Regulatory Powers of the State, Ife 